\title{
Article \\ Applicability Evaluation of Soil Algae Pipe Assay in Silver Nanoparticle-Contaminated Soils
}

\author{
Jin Il Kwak ${ }^{+}{ }^{+}$, Sun-Hwa Nam ${ }^{\dagger}$ and Youn-Joo An *(D) \\ Department of Environmental Health Science, Konkuk University, 120 Neungdong-ro, Gwangjin-gu, \\ Seoul 05029, Korea; kjigod@konkuk.ac.kr (J.I.K.); ciel0001@konkuk.ac.kr (S.-H.N.) \\ * Correspondence: anyjoo@konkuk.ac.kr; Fax: +82-2-2201-6295 \\ + These authors contributed equally to this work.
}

Citation: Kwak, J.I.; Nam, S.-H.; An, Y.-J. Applicability Evaluation of Soil Algae Pipe Assay in Silver Nanoparticle-Contaminated Soils. Appl. Sci. 2022, 12, 1890. https:// doi.org/10.3390/app12041890

Academic Editor: Francesca Scargiali

Received: 24 December 2021

Accepted: 8 February 2022

Published: 11 February 2022

Publisher's Note: MDPI stays neutral with regard to jurisdictional claims in published maps and institutional affiliations.

Copyright: () 2022 by the authors Licensee MDPI, Basel, Switzerland. This article is an open access article distributed under the terms and conditions of the Creative Commons Attribution (CC BY) license (https:// creativecommons.org/licenses/by/ $4.0 /)$.

\begin{abstract}
Due to pervasive and resilient soil contaminants, heterogeneously contaminated soil poses unpredictable potential threats to ecosystems. In this study, the extension of a previously developed soil algae pipe assay for evaluating heterogeneously contaminated soil under an open system is described. The assay can be used in soil that is heterogeneously contaminated with silver nanoparticles in combination with the examination of morphological changes (e.g., in vivo chlorophyll $a$, cell granularity, cell size, and mucilaginous sheath) and lipid contents. In addition, we attempted to extend the exposure duration under an open system. We evaluated the applicability of this soil algae pipe assay using green alga Chlamydomonas reinhardtii exposed to heterogeneous and homogeneous polyvinylpyrrolidone capping silver nanoparticles in contaminated soils. The results demonstrated that this method is an applicable bioassay that can be employed to better evaluate soil algal toxicity under an open system, with significant changes in the measured endpoints. The developed assay showed decent predictivity, which can be a useful tool when evaluating heterogeneous soil algae contamination.
\end{abstract}

Keywords: biomonitoring; silver nano; soil alga; soil contamination

\section{Introduction}

To evaluate the impact of pollutants in the soil environment, it is important to recognize the significance of an integrated approach with real bioavailability via bioassay, as well as measured pollutants via chemical analysis [1]. Under international standard test guidelines for soil ecotoxicity assessments, limited soil toxicity test species were recommended, namely, plants, earthworms, and springtails [2]. For the better probabilistic ecological risk assessments based on species sensitivity distributions, the development of test species in a new taxonomic group is required, and algae could be a potential candidate for soil tests. Soil algae, spread on and beneath the soil, are primary microflora and a valuable food source for mesofauna and microfauna [3,4]. Currently, various test methods in soil ecotoxicity have been developed using algae via whole soil [3,5-7] or soil with intermediate carriers [7-11]. Using these methods, the evaluation, growth, photosynthesis, morphology, or physiology of green algae (e.g., Chlamydomonas, Chlorella, Chlorococcum, Klebsormidium, and Prasiola) have been quantified. In particular, Nam et al. [7] and Kwak et al. [11] developed an algae-soaked disc seeding assay as an indirect bioindicator and a soil algae pipe assay as a direct bioindicator under a non-sterile open system (field and greenhouse experiments, respectively). In a previous study [11], we presented a decrease in in vivo chlorophyll $a$ fluorescence for green alga Chlamydomonas reinhardtii after exposure to heavy metal-contaminated soils by a soil algae pipe assay. The results of that study identified that a soil algae pipe assay was effective for direct soil quality assessments in a pot test. However, Kwak et al. [11] only assessed the chlorophyll content of C. reinhardtii in homogenous soils collected from the field after 7 days. In this study, we extended our experiment 
to evaluate its applicability in the following two cases: (1) when applied to an extended exposure duration under the open system; (2) when applied to a heterogeneously contaminated soil, along with the examination of cell granularity, cell size, and lipid contents using flow cytometry after a soil algae pipe assay. Silver nanoparticles (AgNPs) were studied as the test chemical due to their extensive use in practical life [12,13] and their adverse effects on plants [14-16], arthropods [17,18], oligochaete earthworms [19], soil algae [20], and exoenzymes [21]. C. reinhardtii is widely dispersed in freshwater and soil and has been used as a soil test species in previous studies $[7,11,22]$. To the best of our knowledge, this is the first study that evaluates the applicability of a soil algae pipe assay considering long-term exposure duration and heterogeneously contaminated soil under open system, as part of an efficient soil algae pipe assay.

\section{Materials and Methods}

\subsection{Test Chemicals}

Powdered AgNPs (<80 nm particle size, 3-4\% polyvinylpyrrolidone as a capping agent, 99.5\% purity) were purchased from Sigma-Aldrich (Saint Louis, MO, USA). An average surface area of $1.8498 \pm 0.0191 \mathrm{~m}^{2} / \mathrm{g}$ was measured using a surface area analyzer (Microtrac, Montgomeryville, PA, USA), and the morphology was measured using a field emission transmission electron microscope (FE-TEM; TECNAI G² F30 ST, 300 kV; FEI Co., Hillsboro, OR, USA). Figure 1A shows the irregular morphology of tested AgNPs. The distribution and level of AgNPs in $500 \mathrm{mg} \mathrm{AgNPs/kg} \mathrm{(dry} \mathrm{weight)} \mathrm{soil} \mathrm{were} \mathrm{measured} \mathrm{by}$ the FE-TEM with an energy-dispersive X-ray spectroscopy detector (EDX; XFlash detector 5010; Bruker, USA) as shown in Figure 1B-D.
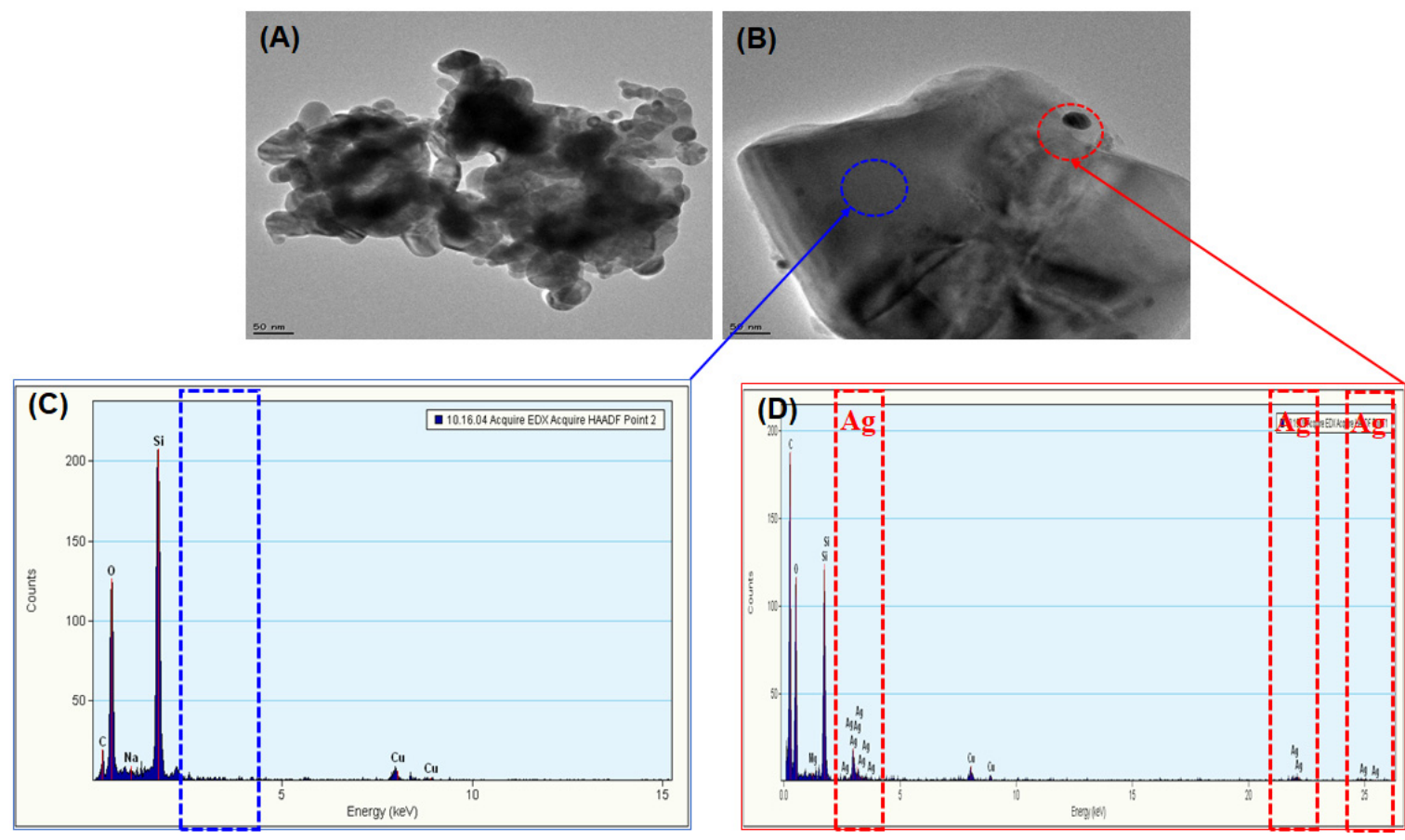

Figure 1. Field emission transmission electronic micrograph (FE-TEM) images of silver nanoparticles (AgNPs). (A) Morphology of AgNPs, (B) FE-TEM image of AgNPs in the tested soil at $500 \mathrm{mg}$ AgNPs/kg dw, (C,D) energy-dispersive X-ray spectroscopy detector spectra of an electron dense spot for adsorption of AgNPs on the soil surface. The red circle indicates the presence of AgNPs on the soil surface; the blue circle indicates the absence of AgNPs in normal soil.

\subsection{Test Soil}

Natural soil was air-dried and sieved using a $2 \mathrm{~mm}$ mesh. The main physicochemical characteristics of the test soils were loamy sand (93\% sand, $6.8 \%$ silt, and $0.2 \%$ clay) with 
a pH of 5.6, an organic matter content of $3.39 \%$, a water-holding capacity of $0.54 \mathrm{~mL} / \mathrm{g}$, available phosphate of $24 \mathrm{mg} / \mathrm{kg}$, total nitrogen of $375 \mathrm{mg} / \mathrm{kg}$, calcium of $9.43 \mathrm{Cmol}^{+} / \mathrm{kg}$, potassium of $0.18 \mathrm{Cmol}^{+} / \mathrm{kg}$, and magnesium of $0.4 \mathrm{Cmol}^{+} / \mathrm{kg}$. Natural soil was spiked with powdered AgNPs at nominal concentrations of $200 \mathrm{mg}$ AgNPs $/ \mathrm{kg}$ soils and thoroughly mixed on a roller $(40 \mathrm{r} / \mathrm{min})$ for $72 \mathrm{~h}$. Then, the $200 \mathrm{mg} \mathrm{AgNPs} / \mathrm{kg}$ soils were diluted in untreated soil to obtain the final concentration of $20 \mathrm{mg} \mathrm{AgNPs} / \mathrm{kg}$.

\subsection{Experimental Design and Set Up}

To evaluate the applicability of the soil algae pipe assay for its dependence on exposure duration and the heterogeneous distribution of AgNP contaminants, three distributed soils were used: Control, heterogeneous AgNP-contaminated soil (hetero), and homogeneous AgNP-contaminated soil (homo). A schematic of the differently distributed soil is provided in Figure 2. To prepare the heterogeneous AgNP-contaminated soil, $1350 \mathrm{~g}$ portions of untreated soil were placed in open plastic pots $(15 \times 15 \times 15 \mathrm{~cm})$, and $450 \mathrm{~g}$ of $20 \mathrm{mg}$ AgNPs $/ \mathrm{kg}$ soil was covered over the untreated soil. To prepare the homogeneous AgNPcontaminated soil, $1800 \mathrm{~g}$ portions of $20 \mathrm{mg}$ AgNPs $/ \mathrm{kg}$ soil were placed in the pots. Subsequently, all soils in the pots were hydrated with a 30\% $(v / w) \mathrm{N}$-free Hoagland solution [23] and were aged for 7 days in a greenhouse $\left(15-25^{\circ} \mathrm{C}\right.$, humidity $\left.50-60 \%\right)$.

(A)

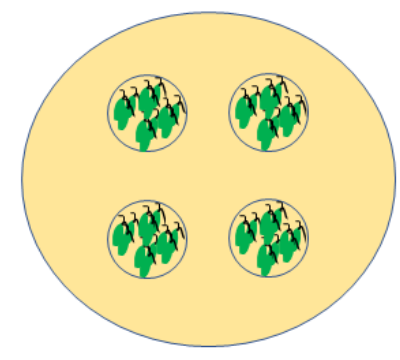

Clean soil $20 \mathrm{mg} \mathrm{AgNPs/kg} \mathrm{soil} \mathrm{Soil} \mathrm{alga}$

(B)

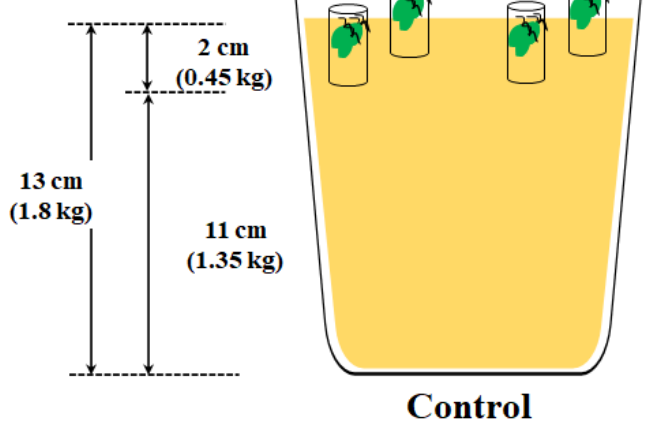

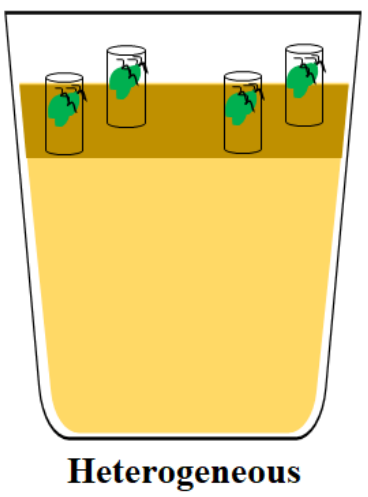

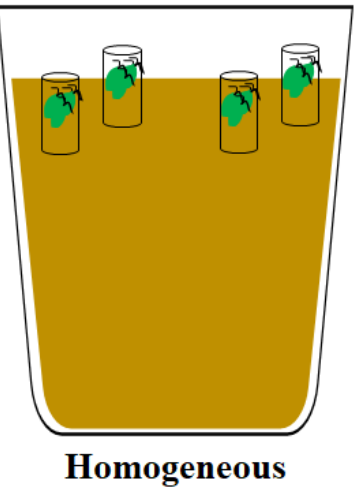

Figure 2. Schematic of different distributions of AgNP-contaminated soil. (A) The upper image of test pot, (B) The side images of control, heterogeneous AgNP-contaminated soil, and homogeneous AgNP-contaminated soil.

This study referred to the soil algae pipe assay from Kwak et al. (2019). Green alga, Chlamydomonas reinhardtii (UTEX No. 2244), was purchased from the University of Texas, Austin (USA). Incubation was conducted in a Tris-acetate-phosphate medium at $24 \pm 2{ }^{\circ} \mathrm{C}$ and shaken at $100 \mathrm{rpm}$ under a $16: 8 \mathrm{~h}$ light:dark photoperiod provided by cool-white fluorescent lamps $\left(54 \mu \mathrm{mol}\right.$ photons $\left./ \mathrm{m}^{2} \cdot \mathrm{s}^{1}\right)$. Two UV-sterilized plastic pipes (diameter $\times$ length, $2 \times 3 \mathrm{~cm}$ ) were planted on both sides of each pot at a $2 \mathrm{~cm}$ depth in the surface soil in four replicates. Pre-cultured soil alga $(1 \mathrm{~mL})$ in the exponential growth phase $\left(\mathrm{OD}_{660}=2.0\right)$ was inoculated on the surface soil in each pipe. To moisten the soil, tap water was provided at intervals of 2-3 days. After 1 and 4 weeks, the pipes were collected from each pot, and a portion of soil alga grown on the surface soil was sampled. The sampled soil algae were detached from the soil during the $24 \mathrm{~h}$ incubation 
period in Bold's Basal medium and then analyzed using flow cytometry (FACSCalibur, BD Biosciences, NJ, USA). Microscopic images were observed by light microscopy (BX-51; Olympus, Tokyo, Japan). Flow cytometric analysis was only applied to the soil algae sampled after 1 week exposure. Cell size, cell granularity, and in vivo chlorophyll $a$ were detected via forward scattered light (FSC), side scattered light (SSC), and FL3 (670 nm band pass filter, excitation at $488 \mathrm{~nm}$ blue laser, $15 \mathrm{~mW}$, argon ion laser), respectively. The lipid contents were detected via FL2 (564-606 nm band pass filter) after staining with Nile red for the determination of intracellular neutral lipid in algae [24]. Nile red powders were dissolved in acetone to obtain a $250 \mu \mathrm{g} / \mathrm{mL}$ solution, and the stock solution was stored at $4{ }^{\circ} \mathrm{C}$ until use. Subsequently, a working solution was prepared by diluting the stock solution 200 times with a mixture of dimethyl sulfoxide and Bold's Basal medium (1:3). Finally, soil algae were stained with Nile red at the rate of 1:1 for $10 \mathrm{~min}$ (dark, room temp.). The geometric means of the FSC, SSC, FL3, and FL2 intensities were normalized based on 10,000 events in the gated soil alga population.

\subsection{Statistical Analysis}

Chlorophyll $a$, cell size, cell granularity, and lipid contents were normalized with the control group. The differences between all data were considered statistically significant at $p<0.05$ according to Dunnett's test [25].

\section{Results and Discussion}

\subsection{Observed Effects of Soil Algae over the Exposure Duration}

The growth of $C$. reinhardtii under different distributions of AgNP-contaminated soil after 1 week is shown in Figure 3. As displayed in Figure 3A,F,K, remarkable growth of $C$. reinhardtii in all the pipes after 1 week was observed with a green color over the surface soil, compared to the soil background color. Figure $3 \mathrm{C}, \mathrm{H}, \mathrm{M}$ present examples of the C. reinhardtii cells in the control and the different distributions of the AgNP-contaminated soil groups (hetero and homo) after 1 week. The formation of mucilaginous sheaths enlarged from $C$. reinhardtii cells were exhibited in the control and AgNP-contaminated soil groups after 1 week (dotted inset in Figure 3C,H,M), as observed in Nam et al. [20] The formation of mucilaginous sheath in soil algae has been known as a protective mechanism to provide moisture or nutrients under stressors (e.g., desiccation, predators, chemicals, and nutrient deficiencies) [26-35]. In this case, the mucilaginous sheath in C. reinhardtii was observed in all control and AgNP-contaminated soil groups after 1 week. Therefore, the mucilaginous sheath of $C$. reinhardtii may be formed to provide moisture against desiccation and not only for protection against the toxicity of the AgNPs. Moreover, both the heterogeneous and homogeneous AgNP-contaminated soil groups exhibited more partially hollow $\mathrm{C}$. reinhardtii cells than the control group (Figure $3 \mathrm{H}, \mathrm{M}$ ). After exposure, the AgNPs may cause morphological changes in C. reinhardtii, thereby inducing the loss of photosynthetic pigments in undeveloped chloroplasts in non-viable or chlorotic cells [36], the expansion of mitochondria, and the weakening of plasma membrane integrity in necrotic cells [37].

As shown in Figure 3D,I,N, noticeable growth of soil algae under different distributions of AgNP-contaminated soil after 4 weeks was observed with a dark green color over the dry surface soil which was greater extent compared to after 1 week. Figure 3E,J,O present examples of soil algae cells in the control and different distributions of AgNP-contaminated soil groups (hetero and homo) after 4 weeks. Unlike after 1 week, non-target organisms were observed in the control, and there were different distributions of AgNP-contaminated soil groups (orange arrows in Figure 3E,J,O). Soil algal suspension extracted from the pipes included non-target organisms, which is probably due to biological soil crusts. Biological soil crusts, which commonly appear in open and arid areas, are formed by combinations of soil particles and various groups of organisms (e.g., cyanobacteria, algae, fungi, bacteria, archaea, lichens, and bryophytes) [38,39]. The appearance of biological soil crusts may be the result of desiccation resistance and the unintentional introduction of non-target 
organisms provided from the atmosphere, non-sterile tap water, and non-sterile soils, under an open soil algae pipe assay. Previous studies have shown that after 4 weeks of exposure, unintentionally formed biological soil crusts have potential interference effects on target soil algae analysis, because physicochemical characteristics of soil (e.g., aggregate stability, water retention, organic matters) can be altered by biological soil crusts [39-42], and the target soil algae and non-target organisms can become mixed in the samples. Therefore, the soil algae pipe assay is not applicable for 4 weeks of exposure due to biological soil crusts unintentionally forming in an open system. These results indicated that evaluation period of soil contamination by applying soil algae pipe assay under the open system should be under 4 weeks in the environmental management view.
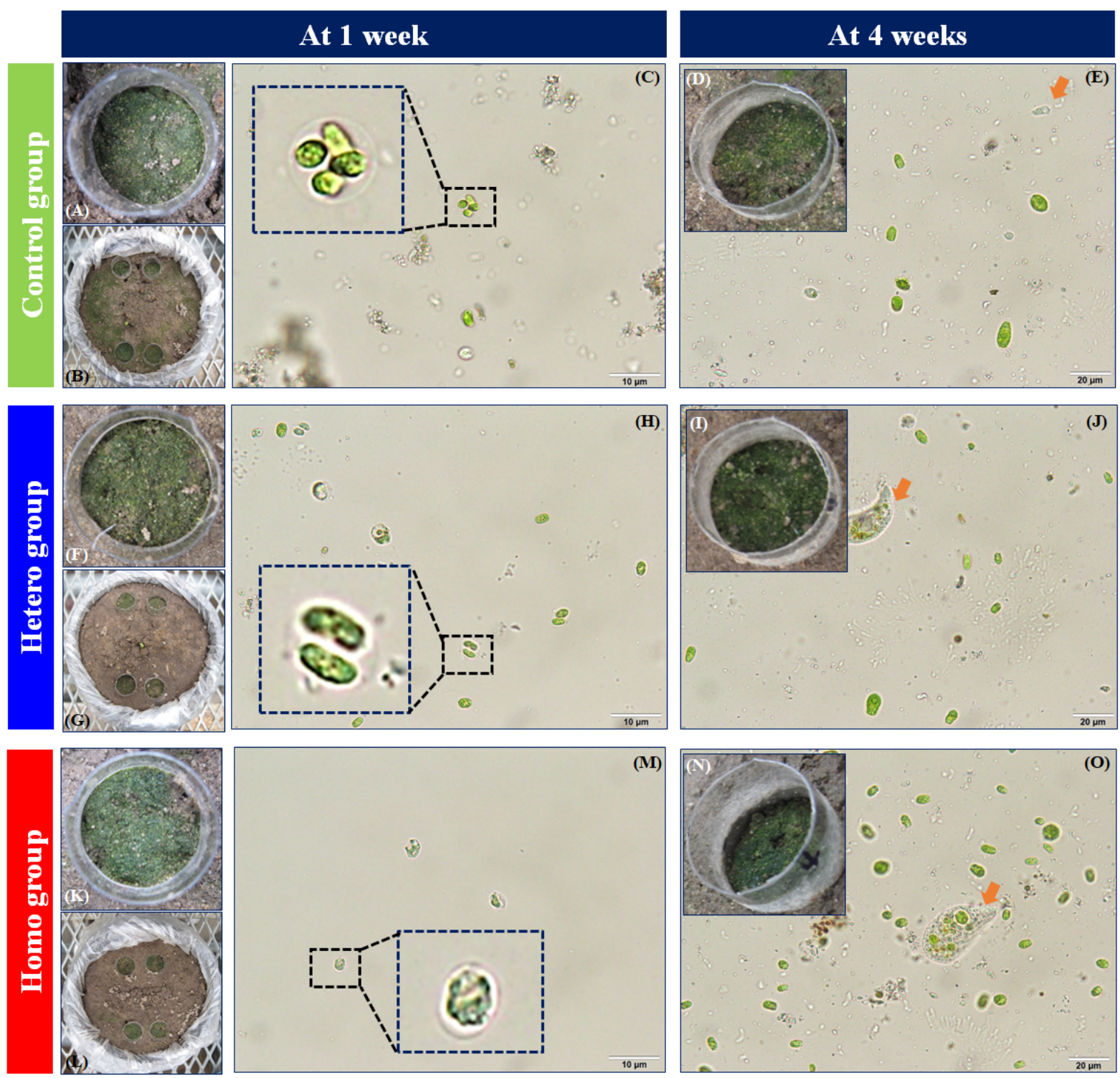

Figure 3. Macroscopy and microscopy images of soil algae extracted from the pipe planted in the control, heterogeneous AgNP-contaminated soil (hetero), and homogeneous AgNP-contaminated soil (homo) at 1 and 4 weeks. (A,D,F,I,K,N): Inside of the pipe, $(\mathbf{B}, \mathbf{G}, \mathbf{L})$ : the upper of the pot, and $(\mathbf{C}, \mathbf{E}, \mathbf{H}, \mathbf{J}, \mathbf{M}, \mathbf{O})$ : organisms extracted from the pipe. Black dotted boxes indicate the presence of mucilaginous sheath enlarged from the algal cells. Orange arrows indicate the presence of non-target organisms extracted from the pipe. Bar for $(\mathbf{C}, \mathbf{H}, \mathbf{M})=10 \mu \mathrm{m}$, while that for $(\mathbf{E}, \mathbf{J}, \mathbf{O})=20 \mu \mathrm{m}$. 


\subsection{Evaluation of Different Distributions of AgNP-Contaminated Soil in Assay}

Figure 4 shows the in vivo chlorophyll $a$, cell granularity, cell size, and lipid contents of C. reinhardtii exposed to different distributions of AgNP-contaminated soil at 1 week. C. reinhardtii cells in both heterogeneous and homogeneous AgNP-contaminated soil groups showed a significant decrease in in vivo chlorophyll $a(p<0.05)$, as indicated by left shifts in the histograms in Figure 4B. This indicated a decrease in chlorophyll contents in each C. reinhardtii cells due to the AgNPs, and we observed partially hollow C. reinhardtii cells showing the loss of photosynthetic pigments in undeveloped chloroplasts in Section 3.1. A decrease in chlorophyll content in algal cells has been commonly observed with the growth inhibition of algae exposed to nanomaterials [20,43-48]. Meanwhile, cell granularity, cell size, and lipid contents were significantly changed in the homogeneous AgNP-contaminated soil group $(p<0.05)$, as indicated by left or right shifts in the histograms in Figure 4C-E. In a previous study of nanomaterials toxicity, the characterization of the nano-bio interaction between nanomaterials and algae has been analyzed by flow cytometry. Changes in cell granularity and cell size were explained as shifts in the SSC and FSC in flow cytometry [49]. An increase in SSC indicates the internalization of nanomaterials into algal cells [50-52] and an increase in FSC indicates the adsorption of nanomaterials to the algal cell wall [53] or the production of a mucilaginous sheath enlarged from the algal cell wall [20]. In this study, the decrease in cell granularity and cell size was significant in the homogeneous AgNP-contaminated soil group (Figures 3D and 4A,C).

This phenomenon may be induced by necrosis and immaturity. Necrosis is cell death resulting from the leakage of cell components or the damage of plasma membrane, as reflected by a decrease in SSC and FSC [37]. In particular, the loss of photosynthetic pigments in undeveloped chloroplasts by AgNPs has a decisive effect on the decrease in cell granularity, organizing microscopic and SSC analysis. In addition, immaturity by AgNPs may influence the decrease in cell size, thereby distributing immature cells (e.g., motile zoosporangia or zoospores, and non-motile aplanosporangia or aplanospores) instead of mature vegetative cells [7], along with the disappearance of big C. reinhardtii cells exposed to silica-coated quantum dots (with a decrease in average cell size and increase in cell count) [54]. A significant increase in the lipid contents was observed in the homogeneous AgNP-contaminated soil group (Figure 4A,E). Lipid accumulation commonly appears in algal cells as a stress-dependent mechanism [55], as storing lipids excludes toxic molecules during the main metabolism [56] and acts as an electron sink to maintain cellular redox homeostasis and prevent oxidative damage [57]. Lipid was accumulated under AgNPs stress, which agreed with the results of other stressors, such as nutrients [34,58,59], and nanomaterials $[44,56,60-62]$. When the $C$. reinhardtii cells were exposed to homogeneous $20 \mathrm{mg} / \mathrm{kg}$ AgNP-contaminated soil, a decrease in in vivo chlorophyll $a$, cell granularity, and cell size, and an increase in lipids showed significant differences compared to the control. On the other hand, when the C. reinhardtii cells were exposed to heterogeneous $20 \mathrm{mg} / \mathrm{kg}$ AgNP-contaminated soil, only the decrease in in vivo chlorophyll $a$ was significantly different compared to the control group $(p<0.05)$ and a significant difference in in vivo chlorophyll $a$ was observed compared to the homogeneous $20 \mathrm{mg} / \mathrm{kg}$ AgNP-contaminated soil, as illustrated in Figure 4A. This difference in toxicity sensitivity may have resulted from the heterogeneous and homogeneous distribution range of AgNP-contaminated soils (Figure 5). In this exposure system, the exposure concentration of homogeneous $20 \mathrm{mg} / \mathrm{kg}$ AgNP-contaminated soil is regarded as $20 \mathrm{mg} / \mathrm{kg}$ just as it was in the pot. However, the average exposure concentration of heterogeneous $20 \mathrm{mg} / \mathrm{kg}$ AgNP-contaminated soil is simply converted into $5 \mathrm{mg} / \mathrm{kg}$ as it was composed of $25 \%$ AgNP-contaminated soil and $75 \%$ uncontaminated soil. Although the soil algae pipe was planted in $20 \mathrm{mg} / \mathrm{kg}$ AgNP-contaminated soil, the effect of less than $20 \mathrm{mg} / \mathrm{kg}$ AgNP in the contaminated soil in the heterogeneous pot may be induced by the $C$. reinhardtii cells. 

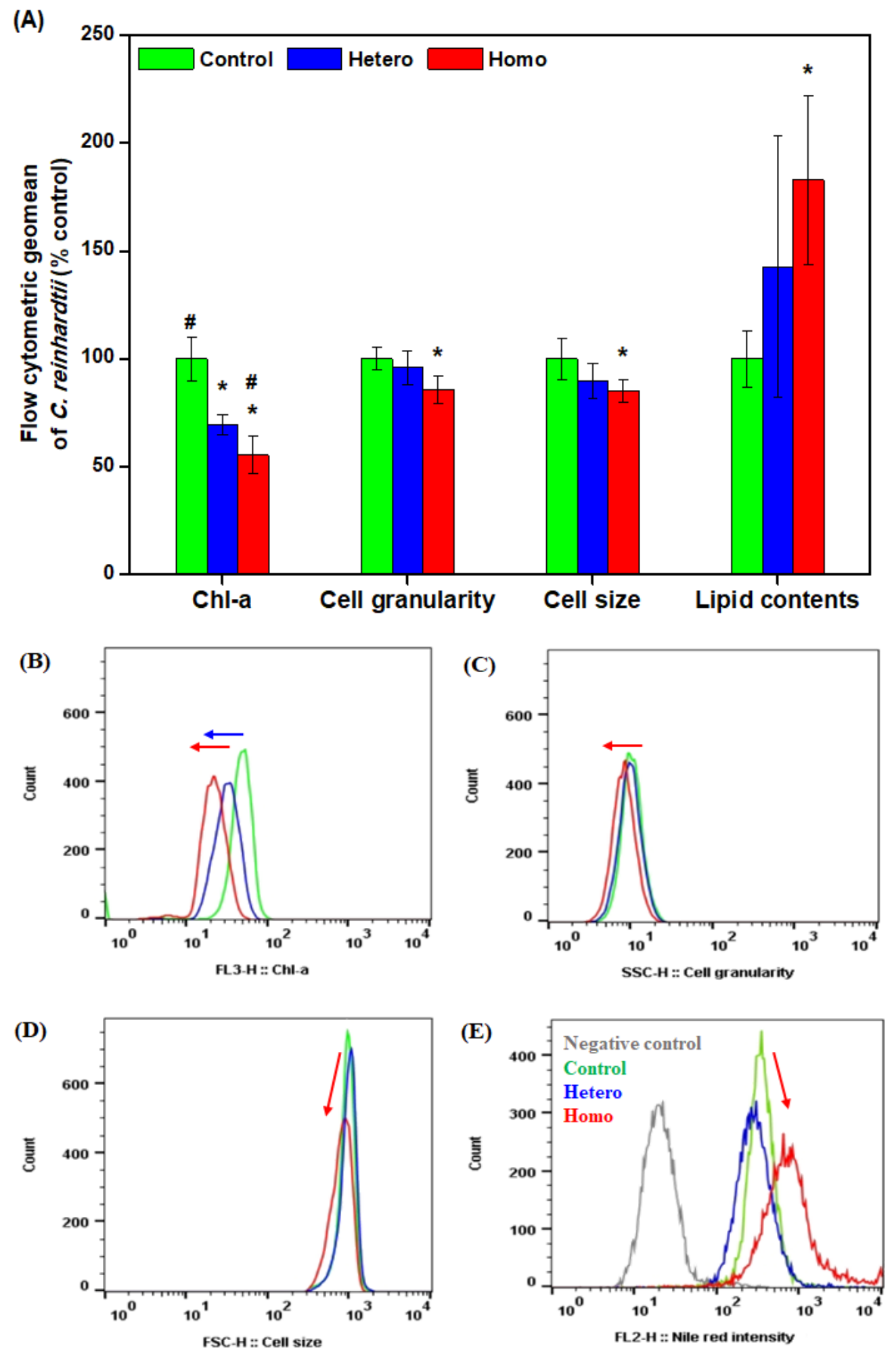

Figure 4. Flow cytometric analysis of soil algae extracted from the pipe planted in the control, heterogeneous AgNP-contaminated soil (hetero), and homogeneous AgNP-contaminated soil (homo) at 1 week. (A) Flow cytometric statistics of soil alga $(n=3-4),($ B-E) flow cytometric histogram of soil alga ((B) chlorophyll, (C) cell granularity, (D) cell size, and (E) lipid contents). Asterisks (*) indicate results that are significantly different from the control $(p<0.05)$. Crosshatches $(\#)$ indicate results that are significantly different from the topsoil $(p<0.05)$. Blue or red arrows indicate significant difference of each parameter from the control. 


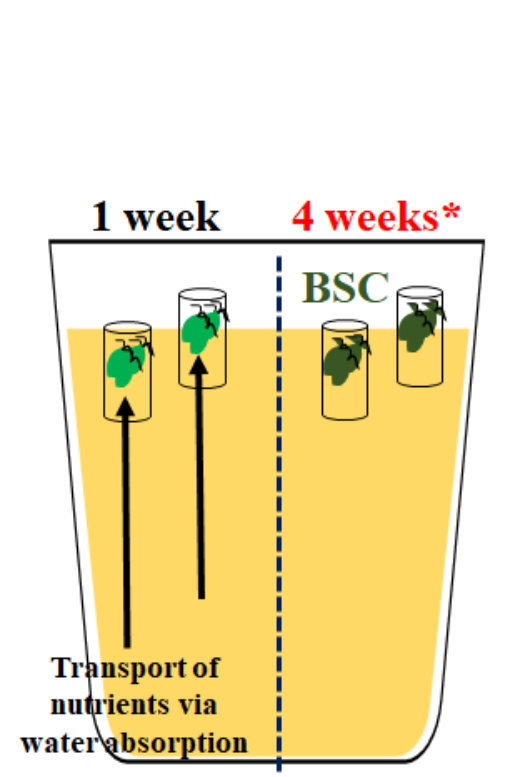

Control
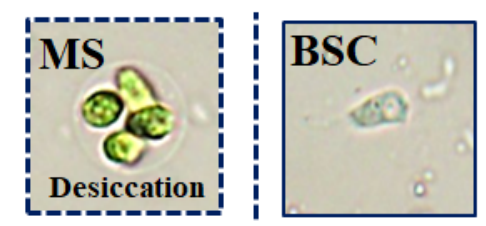

Chl-a $\downarrow$

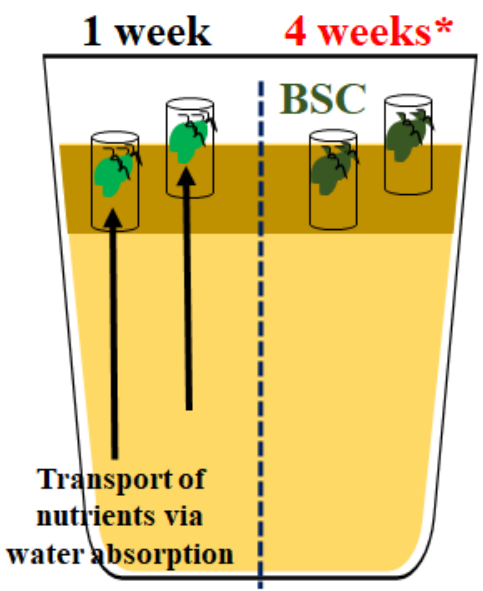

Heterogeneous

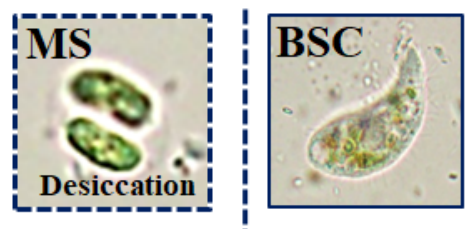

Chl-a $\downarrow$

Cell granularity

Cell size

Lipid contents $\downarrow$

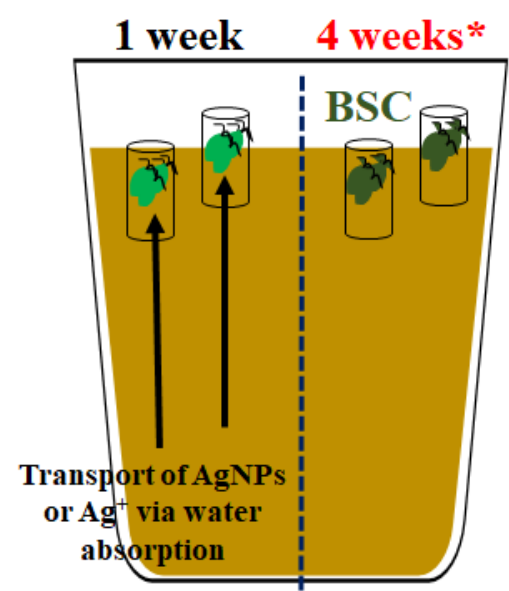

Homogeneous

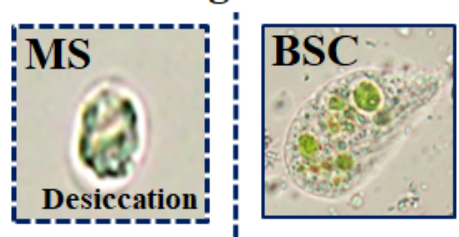

* Appearance of non-target organisms

provided from the atmosphere, non-sterile tap water, and non-sterile soils

\section{Clean soil $20 \mathrm{mg} \mathrm{AgNPs/kg} \mathrm{soil} \mathrm{Soil} \mathrm{alga}$}

\section{BSC (biological soil crusts) MS (mucilaginous sheath enlarged from algal cells)}

Figure 5. A schematic diagram representing transport of nutrients or stressors via water absorption and formation of mucilaginous sheath enlarged from algal cells under desiccation in the control, heterogeneous AgNP-contaminated soil (hetero), and homogeneous AgNP-contaminated soil (homo) after 1 week, and appearance of non-target organisms (biological soil crusts) provided from the atmosphere, non-sterile tap water, and non-sterile soils after 4 weeks.

The alleviated toxicity in heterogeneous AgNP-contaminated soil compared to homogeneous AgNP-contaminated soil may be due to pore water absorption of the upper soil layer from the lower layer as shown in tomato and alfalfa plants under salt stress [63,64]. Chen et al. [63] reached similar results with tomato plants exposed to heterogeneous salt distributed soils, where the toxicity of heterogeneous $\mathrm{T}_{1: 5}$ (soil salt contents in the upper and lower soil layer were $1 \%$ and $5 \%$, respectively) was alleviated as shown by the biomass and photosynthesis of the tomato plants in comparison to homogeneous $\mathrm{T}_{3: 3}$ (soil salt contents in the upper and lower soil layer were 3\%o and 3\%o). In homogeneous AgNP-contaminated soil, AgNPs adsorbed in the lower soil surface may be re-released into the pore water due to the low retention of polyvinylpyrrolidone capping AgNPs in soil [65]. The pore water from the lower soil layer may be absorbed by C. reinhardtii over time, significantly affecting it in the end. Meanwhile, in the heterogeneous AgNP-contaminated soil, non-AgNPs (e.g., nutrients) adsorbed in the lower soil surface may be re-released into the pore water and may be advantageously taken in by C. reinhardtii. The reactive surface area of AgNPs themselves or silver ions dissolved from AgNPs are known to be the main causes of the adverse effects of AgNPs on soil organisms [17-20,66,67]. In other words, a 
soil algae pipe assay may be eventually influenced by the average exposure concentration due to pore water absorbed vertically from the other soil layers, even in heterogeneous soil. Even though the present study focused on applicability to evaluation of soil algae pipe assay, the limitations of analyses of toxic mechanisms of AgNPs to soil algae can be identified as follows. First, unclear bioaccumulated silver concentration in the algae remained; nevertheless, some previous studies reported the effects AgNPs themselves or silver ions dissolved from AgNPs on soil organisms including plants, isopod, springtail, worm, and soil alga [17-20,66,67]. Next, toxicity contribution of PVP (polyvinylpyrrolidone) to soil algae were not investigated. It is estimated that $20 \mathrm{mg} \mathrm{AgNPs} / \mathrm{kg}$ soil contained 0.6-0.8 mg PVP $/ \mathrm{kg}$ soil. It was reported that the $\mathrm{LD}_{50}$ (medium lethal dose) of PVP for rats and guinea pigs was estimated to $>100,000 \mathrm{mg} / \mathrm{kg}$ [68]. PVP might be released from the AgNPs and taken up by a plant or other soil organism, which may or may not affect the algae species. Last, interactions between physicochemical properties (including porosity, moisture, water content, infiltration rate, $\mathrm{pH}$, organic content, ORP, oxygen, nutrients etc.) of soil and biological factors under the present test design were not fully monitored. To understand comprehensive toxic mechanism of AgNPs in the present test design, these limitations should be investigated in future studies.

\section{Conclusions}

In this study, we evaluated the applicability of soil algae pipe assay in silver nanoparticlecontaminated soils. This enabled us to observe the inapplicability of extended exposure duration (4 weeks) due to unintentionally formed biological soil crusts and verify that the toxicity evaluation method is influenced by the average exposure concentration due to pore water absorption, even in a heterogeneous AgNP-contaminated soil. Although the results showed that 4 weeks of exposure is not appropriate for soil algae pipe assay under an open system and the toxicity mechanism between soil algae and the AgNPs in soil was not investigated, the results still showed discernible impacts that are valuable as a basis to evaluate heterogeneous contamination on soil algae and the potential risk to ecosystems; for instance, different distributions of biological crusts between control soil and AgNPcontaminated soil groups were observed. All the effects of AgNPs using a soil algae pipe assay can be considered as an applicable bioassay to better evaluate soil algal toxicity under an open system, with discernible results via the evaluation of AgNP-contaminated soil. Future studies should consider various soil algae species and contamination configurations of AgNPs.

Author Contributions: Conceptualization, J.I.K. and Y.-J.A.; methodology, J.I.K. and S.-H.N.; formal analysis, J.I.K. and S.-H.N.; investigation, J.I.K. and S.-H.N.; data curation, S.-H.N.; writing-original draft preparation, S.-H.N. and J.I.K.; writing—review and editing, Y.-J.A.; supervision, Y.-J.A.; funding acquisition, Y.-J.A. All authors have read and agreed to the published version of the manuscript.

Funding: This research was funded by Basic Science Research Program through the National Research Foundation (NRF) of Korea funded by the Ministry of Science, ICT and future planning (2020R1A2B5B02001734). This paper was also supported by Konkuk University Research Fund in 2021.

Institutional Review Board Statement: Not applicable.

Informed Consent Statement: Not applicable.

Data Availability Statement: Not applicable.

Acknowledgments: We thank the Korea Basic Science Institute (KBSI) for the FE-TEM, EDX, and surface area analyzer analyses.

Conflicts of Interest: The authors declare no conflict of interest. 


\section{References}

1. Bonaventura, R.; Zito, F.; Morroni, L.; Pellegrini, D.; Regoli, F.; Pinsino, A. Development and validation of new analytical methods using sea urchin embryo bioassay to evaluate dredged marine sediments. J. Environ. Manag. 2021, 281, 111862. [CrossRef] [PubMed]

2. Nam, S.-H.; An, Y.-J. Investigation of Korean native organisms for development of ecotoxicity test: (2) soil test species. J. Korean Soc. Environ. Eng. 2018, 40, 48-57. [CrossRef]

3. Hammel, W.; Steubing, L.; Debus, R. Assessment of the ecotoxic potential of soil contaminants by using a soil-algae test. Ecotox. Environ. Safe. 1998, 40, 173-176. [CrossRef] [PubMed]

4. Metting, B. The systematics and ecology of soil algae. Bot. Rev. 1981, 47, 196. [CrossRef]

5. Jahnke, J.; Mahlmann, D.M.; Jacobs, P.; Priefer, U.B. The influence of growth conditions on the cell dry weight per unit biovolume of Klebsormidium flaccidum (Charophyta), a typical ubiquitous soil alga. J. Appl. Phycol. 2011, 23, 655-664. [CrossRef]

6. Nam, S.-H.; An, Y.-J. Cell size and the blockage of electron transfer in photosynthesis: Proposed endpoints for algal assays and its application to soil alga Chlorococcum infusionum. Chemosphere 2015, 128, 85-95. [CrossRef]

7. Nam, S.-H.; An, Y.-J. A rapid screening method to assess soil algal toxicity: Non-destructive sampling of algal cells using culture medium extraction. Appl. Soil. Ecol. 2017, 120, 143-152. [CrossRef]

8. Krishnamurti, G.S.R.; Subashchandrabose, S.R.; Megharaj, M.; Naidu, R. Assessment of bioavailability of heavy metal pollutants using soil isolates of Chlorella sp. Environ. Sci. Pollut. Res. 2015, 22, 8826-8832. [CrossRef]

9. Nam, S.-H.; An, Y.-J. Paper-disc method: An efficient assay for evaluating heavy metal toxicity to soil algae. Environ. Pollut. 2016, 216, 1-8. [CrossRef]

10. Nydahl, A.C.; King, C.K.; Wasley, J.; Folley, D.F.; Robinson, S.A. Toxicity of fuel-contaminated soil to antarctic moss and terrestrial algae. Environ. Toxicol. Chem. 2015, 34, 2004-2012. [CrossRef]

11. Kwak, J.I.; Nam, S.-H.; An, Y.-J. Soil algae pipe assay: Ex situ method for the evaluation of soil quality based on soil algae and its application to the pot test. Chemosphere 2019, 224, 634-636. [CrossRef] [PubMed]

12. Boxall, A.B.A.; Chaudhry, Q.; Sinclair, C.; Jones, A.; Aitken, R.; Jefferson, B.; Watts, C. Current and Future Predicted Environmental Exposure to Engineered Nanoparticles; Central Science Laboratory, Department of the Environment and Rural Affairs: London, $\mathrm{UK}, 2007$.

13. Piccinno, F.; Gottschalk, F.; Seeger, S.; Nowack, B. Industrial production quantities and uses of ten engineered nanomaterials in Europe and the world. J. Nanopart. Res. 2012, 14, 1109. [CrossRef]

14. Abd-Alla, M.H.; Nafady, N.A.; Khalaf, D.M. Assessment of silver nanoparticles contamination on faba bean-Rhizobium leguminosarum bv. viciae-Glomus aggregatum symbiosis: Implications for induction of autophagy process in root nodule. Agri. Ecosystem. Environ. 2016, 218, 163-177. [CrossRef]

15. Hossain, Z.; Mustafa, G.; Sakata, K.; Komatsu, S. Insights into the proteomic response of soybean towards $\mathrm{Al}_{2} \mathrm{O}_{3}, \mathrm{ZnO}$ and $\mathrm{Ag}$ nanoparticles stress. J. Hazard. Mater. 2016, 304, 291-305. [CrossRef] [PubMed]

16. Rastogi, A.; Zivcak, M.; Tripathi, D.K.; Yadav, S.; Kalaji, H.M. Phytotoxic effect of silver nanoparticles in Triticum aestivum Improper regulation of photosystem I activity as the reason for oxidative damage in the chloroplast. Photosynthetica 2019, 57, 209-216. [CrossRef]

17. Tourinho, P.S.; van Gestel, C.A.M.; Jurkschat, K.; Soares, A.M.V.M.; Loureiro, S. Effects of soil and dietary exposures to Ag nanoparticles and $\mathrm{AgNO}_{3}$ in the terrestrial isopod Porcellionides pruinosus. Environ. Pollut. 2015, 205, 170-177. [CrossRef]

18. Waalewijn-Kool, P.L.; Klein, K.; Forniès, R.M.; van Gestel, C.A.M. Bioaccumulation and toxicity of silver nanoparticles and silver nitrate to the soil arthropod Folsomia candida. Ecotoxicology 2014, 23, 1629-1637. [CrossRef]

19. Gomes, S.I.L.; Soares, A.M.V.M.; Scott-Fordsmand, J.J.; Amorim, M.J.B. Mechanisms of response to silver nanoparticles on Enchytraeus albidus (Oligochaeta) Survival, reproduction and gene expression profile. J. Hazard. Mater. 2013, 254-255, 336-344. [CrossRef]

20. Nam, S.-H.; Kwak, J.I.; An, Y.-J. Quantification of silver nanoparticle toxicity to algae in soil via photosynthetic and flow-cytometric analyses. Sci. Rep. 2018, 8, 292. [CrossRef]

21. Shin, Y.J.; Kwak, J.I.; An, Y.-J. Evidence for the inhibitory effects of silver nanoparticles on the activities of soil exoenzymes. Chemosphere 2012, 88, 524-529. [CrossRef]

22. Nam, S.-H.; Moon, J.; Kim, S.W.; Kim, H.; Jeong, S.-W.; An, Y.-J. Rapid in situ assessment for predicting soil quality using an algae-soaked disc seeding assay. Environ. Monit. Assess. 2017, 189, 637. [CrossRef] [PubMed]

23. Hoagland, D.R.; Arnon, D.I. The water-culture method for growing plants without soil. In Circular, 2nd ed.; California Agricultural Experiment Station: Berkeley, CA, USA, 1950; p. 347.

24. Cooksey, K.E.; Guckert, J.B.; Williams, S.A.; Callis, P.R. Fluorometric determination of the neutral lipid content of microalgal cells using Nile Red. J. Microbiol. Meth. 1987, 6, 333-345. [CrossRef]

25. Dunnett, C.W. Multiple comparison procedure for comparing several treatments with a control. J. Am. Stat. Assoc. 1995, 50, 1096-1121. [CrossRef]

26. Bold, H.C. Life history and cell structure of Chlorococcum infusionum. Bullet. Torrey. Bot. Club 1930, 57, 577-604. [CrossRef]

27. Hu, C.; Liu, Y.; Paulsen, B.S.; Petersen, D.; Klaveness, D. Extracellular carbohydrate polymers from five desert soil algae with different cohesion in the stabilization of fine sand grain. Carbohyd. Polym. 2003, 54, 33-42. [CrossRef] 
28. Mazor, G.; Kidron, G.J.; Vonshak, A.; Abeliovich, A. The role of cyanobacterial exopolysaccharides in structuring desert microbial crusts. FEMS. Microbiol. Ecol. 1996, 21, 121-130. [CrossRef]

29. Boney, A.D. Mucilage: The ubiquitous algal attribute. Br. Phycol. J. 1981, 16, 115-132. [CrossRef]

30. Lurling, M.; Beekman, W. Palmelloids formation in Chlamydomonas reinhardtii: Defence against rotifer predators? Ann. Limnol. Int. J. Lim. 2006, 42, 65-72. [CrossRef]

31. Iwasa, K.; Murakami, S. Palmelloid formation of Chlamydomonas. I. Palmelloid induction by organic acids. Physiol. Plantarum 1968, 21, 1224-1233. [CrossRef]

32. Jamers, A.; De Coen, W. Effect assessment of the herbicide paraquat on a green alga using differential gene expression and biochemical biomarkers. Environ. Toxicol. Chem. 2010, 29, 893-901. [CrossRef]

33. Neelam, S.; Subramanyam, R. Alteration of photochemistry and protein degradation of photosystem II from Chlamydomonas reinhardtii under high salt grown cells. J. Photoch. Photobiol. B. 2013, 124, 63-70. [CrossRef] [PubMed]

34. Khona, D.K.; Shirolikar, S.M.; Gawde, K.K.; Hom, E.; Deodhar, M.A.; D'Souza, J.S. Characterization of salt stress-induced palmelloids in the green alga, Chlamydomonas reinhardtii. Algal. Res. 2016, 16, 434-448. [CrossRef]

35. Olsen, Y.; Knutsen, G.; Lien, T. Characteristics of phosphorus limitation in Chlamydomonas reinhardtii. J. Phycol. 1983, 19, 313-319. [CrossRef]

36. Prado, R.; Rioboo, C.; Herrero, C.; Cid, A. Characterization of cell response in Chlamydomonas moewusii cultures exposed to the herbicide paraquat: Induction of chlorosis. Aqua. Tox. 2011, 102, 10-17. [CrossRef]

37. Darzynkiewicz, X.; Bruno, S.; Del Bino, G.; Gorczyca, W.; Hotz, M.A.; Lassota, P.; Traganos, F. Features of apoptotic cells measured by flow cytometry. Cytometry 1992, 13, 795-808. [CrossRef]

38. Karsten, U.; Holzinger, A. Green algae in alpine biological soil crust communities acclimation strategies against ultraviolet radiation and dehydration. Biodivers. Conserv. 2014, 23, 1845-1858. [CrossRef]

39. Chamizo, S.; Cantón, Y.; Miralles, I.; Domingo, F. Biological soil crust development affects physicochemical characteristics of soil surface in semiarid ecosystems. Soil. Biol. Biochem. 2012, 49, 96-105. [CrossRef]

40. Zhuang, W.; Downing, A.; Zhang, Y. The influence of biological soil crusts on ${ }^{15} \mathrm{~N}$ translocation in soil and vascular plant in a temperate desert of Northwestern China. J. Plant. Ecol. 2015, 8, 420-428. [CrossRef]

41. Faist, A.M.; Herrick, J.E.; Belnap, J.; Van Zee, J.W.; Barger, N.N. Biological soil crust and disturbance controls on surface hydrology in a semi-arid ecosystem. Ecosphere 2017, 8, e01691. [CrossRef]

42. Kakeh, J.; Gorji, M.; Mohammadi, M.H.; Asadi, H.; Khormali, F.; Sohrabi, M.; Cerdá, A. Biological soil crusts determine soil properties and salt dynamics under arid climatic condition in Qara Qir, Iran. Sci. Total. Environ. 2020, 732, 139168. [CrossRef]

43. Stevenson, L.M.; Dickson, H.; Klanjscek, T.; Keller, A.A.; McCauley, E.; Nisbet, R.M. Environmental feedbacks and engineered nanoparticles: Mitigation of silver nanoparticle toxicity to Chlamydomonas reinhardtii by algal-produced organic compounds. PLoS ONE 2013, 8, e74456. [CrossRef] [PubMed]

44. Chae, Y.; An, Y.-J. Toxicity and transfer of polyvinylpyrrolidone-coated silver nanowires in an aquatic food chain consisting of algae, water fleas, and zebrafish. Aqua. Tox. 2016, 173, 94-104. [CrossRef] [PubMed]

45. Oukarroum, A.; Halimi, I.; Siaj, M. Cellular responses of Chlorococcum Sp. algae exposed to zinc oxide nanoparticles by using flow cytometry. Water. Air. Soil. Pollut. 2019, 230, 1. [CrossRef]

46. Hund-Rinke, K.; Schlich, K.; Kúhnel, D.; Hellack, B.; Kaminski, H.; Nickel, C. Grouping concept for metal and metal oxide nanomaterials with regard to their ecotoxicological effects on algae, daphnids and fish embryos. Nanoimpact 2018, 9, 52-60. [CrossRef]

47. Zheng, S.; Zhou, Q.; Chen, C.; Yang, F.; Cai, Z.; Li, D.; Geng, Q.; Feng, Y.; Wang, H. Role of extracellular polymeric substances on the behavior and toxicity of silver nanoparticles and ions to green algae Chlorella vulgaris. Sci. Total Environ. 2019, 660, 1182-1190. [CrossRef]

48. Yin, J.; Dong, Z.; Liu, Y.; Wang, H.; Li, A.; Zhuo, Z.; Feng, W.; Fan, W. Toxicity of reduced graphene oxide modified by metals in microalgae: Effect of the surface properties of algal cells and nanomaterials. Carbon 2020, 169, 182-192. [CrossRef]

49. Nogueira, P.F.M.; Marangoni, V.S.; Zucollotto, V. The aspect ratio of gold nanorods as a cytotoxicity factor on Raphidocelis subcaptata. Environ. Res. 2020, 191, 110133. [CrossRef]

50. Zucker, R.M.; Massaro, E.J.; Sanders, K.M.; Degn, L.L.; Boyes, W.K. Detection of $\mathrm{TiO}_{2}$ nanoparticles in cells by flow cytometry. Cytom. Part A 2010, 77A, 677-685. [CrossRef]

51. Manier, N.; Bado-Nilles, A.; Delalain, P.; Aguerre-Chariol, O.; Pandard, P. Ecotoxicity of non-aged and aged $\mathrm{CeO}_{2}$ nanomaterials towards freshwater microalgae. Environ. Pollut. 2013, 180, 63-70. [CrossRef]

52. Arze, A.R.; Manier, N.; Chatel, A.; Mouneyrac, C. Characterization of the nano-bio interaction between metallic oxide nanomaterials and freshwater microalgae using flow cytometry. Nanotoxicology 2020, 14, 1082-1095. [CrossRef]

53. Nam, S.-H.; An, Y.-J. Size and shape-dependent toxicity of silver nanomaterials in green alga Chlorococcum infusioum. Ecotox. Environ. Saf. 2019, 168, 388-393. [CrossRef] [PubMed]

54. Elzorkany, H.E.; Farghali, M.A.; Hassan, M.A.; El-sayed, K.; Canonico, M.; Konert, G.; Farroh, K.; Elshoky, H.A.; Kaňa, R. Ecotoxicology impact of silica-coated CdSe/ZnS quantum dots internalized in Chlamydomonas reinhardtii algal cells. Sci. Total Environ. 2019, 666, 480-489. [CrossRef] [PubMed]

55. Guo, Y.; Ma, W.; Li, J.; Liu, W.; Qi, P.; Ye, Y.; Guo, B.; Zhang, J.; Qu, C. Effects of microplastics on growth, phenanthrene stress, and lipid accumulation in a diatom, Phaeodactylum tricornutum. Environ. Pollut. 2020, 257, 113628. [CrossRef] [PubMed] 
56. Romero, N.; Visentini, F.F.; Márquez, V.E.; Santiago, L.G.; Castro, G.R.; Gagneten, A.M. Physiological and morphological responses of green microalgae Chlorella vulgaris to silver nanoparticles. Environ. Res. 2020, 189, 109857. [CrossRef] [PubMed]

57. Chia, M.A.; Lombardi, A.T.; Melão, M.G.G.; Parrish, C.C. Combined nitrogen limitation and cadmium stress stimulate total carbohydrates, lipids, protein and amino acid accumulation in Chlorella vulgaris (Trebouxiophyceae). Aqua. Tox. 2015, 87-95. [CrossRef]

58. Breuer, G.; Lamer, P.P.; Martens, D.E.; Draaisma, R.B.; Wijffels, R.H. The impact of nitrogen starvation on the dynamics of triacylglycerol accumulation in nine microalgae strains. Bior. Technol. 2012, 124, 217-226. [CrossRef]

59. Griffiths, M.J.; van Hille, R.P.; Harrison, S.T.L. Lipid productivity, settling potential and fatty acid profile of 11 microalgal species grown under nitrogen replete and limited conditions. J. Appl. Phycol. 2012, 24, 989-1001. [CrossRef]

60. McTeer, J.; Dean, A.P.; White, K.N.; Pittman, J.K. Bioaccumulation of silver nanoparticles into Daphnia magna from a freshwater algal diet and the impact of phosphate availability. Nanotoxicology 2014, 8, 305-316. [CrossRef]

61. He, M.; Yan, Y.; Pei, F.; Wu, M.; Gebreluel, T.; Zou, S.; Wang, C. Improvement on lipid production by Scenedesmus obliquus triggered by low dose exposure to nanoparticles. Sci. Rep. 2017, 7, 15526. [CrossRef]

62. Khanra, A.; Vasistha, S.; Rai, M.P. $\mathrm{ZrO}_{2}$ nanoparticles mediated flocculation and increased lipid extraction in chlorococcum sp. for biodiesel production: A cost effective approach. Mater. Proc. 2020, 28, 1847-1852. [CrossRef]

63. Chen, S.; Wang, Z.; Guo, X.; Rasool, G.; Zhang, J.; Xie, Y.; Hamoud, Y.A.; Shao, G. Effects of vertically heterogeneous soil salinity on tomato photosynthesis and related physiological parameters. Sci. Hortic. 2019, 249, 120-130. [CrossRef]

64. Sun, J.; Yang, G.; Zhang, W.; Zhang, Y. Effects of heterogeneous salinity on growth, water uptake, and tissue ion concentrations of alfalfa. Plant. Soil. 2016, 408, 211-226. [CrossRef]

65. He, J.; Wang, D.; Zhou, D. Transport and retention of silver nanoparticles in soil: Effects of input concentration, particle size and surface coating. Sci. Total Environ. 2019, 648, 102-108. [CrossRef] [PubMed]

66. Lv, J.; Christie, P.; Zhang, S. Uptake, translocation, and transformation of metal-based nanoparticles in plants: Recent advances and methodological challenges. Environ. Sci. Nano 2019, 6, 41. [CrossRef]

67. Yan, A.; Chen, Z. Impacts of silver nanoparticles on plants: A focus on the phytotoxicity and underlying mechanism. Int. J. Mol. Sci. 2019, 20, 1003. [CrossRef]

68. Nair, B. Final report on the safety assessment of polyvinylpyrrolidone (PVP). Int. J. Toxicol. 1998, 17, 95-130. [CrossRef] 